
(Studi Al-Qur'an Surat Al-Furqan: 74 dan Al-Sajdah: 17)

\title{
KONSEP QURROTA A'YUN SEBAGAI KARAKTER ANAK (STUDI AL-QUR'AN SURAT AL-FURQAN: 74 DAN AL-SAJDAH: 17)
}

\author{
${ }^{1}$ Siti Maryam \\ STIT Islamic Village Tangerang \\ email: stmaryam6762@gmail.com
}

\begin{abstract}
Lately, many parents and educators are still complaining about the success of children's character education, especially in adolescence. Teenagers usually tend to violate moral values, ethics, and religious norms such as: undisciplined, not independent, disrespectful, against parents, lazy to learn, leave prayer, violence, fighting, brawls, etc. other. This creates a problem for parties: the government, schools, the community, more specifically for parents. Therefore research on the concept of qurrota $a^{\prime} y u n$ as a child character based on the study of the Qur'an al-Furqan: 74, and as-Sajdah: 17 is important. There are various opinions of the scholars about the concept of qurrota a'yun, namely Ahmad Mustafa alMaraghi, Ibn Kathir Muhammad Nasib ar-Rifa'i, Buya Hamka, and Quraish Shibab. The basic concept of child character education is religious, biological, psychological, sociological. So too, the role of parents and educators in shaping children's character can be done through a religious approach, habituation, emotional, rational, functional and obedience approach.
\end{abstract}

\section{Keywords: Interpretation of Ulama; Character Psychology}

\begin{abstract}
Abstrak: Belakangan ini banyak orang tua dan pendidik yang masih mengeluhkan keberhasilan pendidikan karakter anak, terurama pada usia remaja. Para remaja biasanya cenderung untuk sering melakukan pelanggaran nilai-nilai moral, etika, dan norma-norma agama seperti: tidak disiplin, tidak mandiri, tidak sopan, melawan orang tua, malas belajar, meninggalkan sholat, kekerasan, perkelahian, tawuran, dan lain-lain. Hal ini menimbulkan masalah bagi pihak: pemerintah, sekolah, masyarakat, lebih khusus lagi bagi orang tua. Karena itu penelitian tentang konsep qurrota a'yun sebagai karakter anak berdasarkan studi al-Qur'an surat alFurqan: 74, dan as-Sajdah: 17 penting dilakukan. Terdapat berbagai pendapat para ulama tentang konsep qurrota a'yun, yaitu Ahmad Mustafa al-Maraghi, Ibnu Katsir Muhammad Nasib ar-Rifa'i, Buya Hamka, dan Quraish Shibab. Konsep dasar pendidikan karakter anak adalah agamis, biologis, psikologis, sosiologis. Begitu pula peran orang tua dan pendidik dalam membentuk karakter anak dapat dilakukan melalui pendekatan keagamaan, pembiasaan, emosional, rasional, fungsional dan pendekatan ketauladanan.
\end{abstract}

Kata Kunci: Penafsiran Ulama; Psikologi Karakter

\section{A. PENDAHULUAN}

Pemerintah dewasa ini telah mencanangkan peraturan pemerintah RI tentang perlindungan anak diantaranya terdapat dalam pasar 3 berbunyi "Perlindungan anak bertujuan menjamin terpenuhinya hak-hak anak agar dapat

Peer reviewed under reponsibility of STIT ISLAMIC VILLAGE.

(C) 2018 STIT ISLAMIC VILLAGE, All right reserved, This is an open access article under 73 the CC BY SA license (https://creativecommons.org/licenses/by-sa/4.0/) 
hidup, tumbuh, berkembang, dan berpartisipasi secara optimal sesuai dengan harkat dan martabat, kemanusiaan, serta mendapat perlindungan dari kekerasan dan diskriminasi, demi terwujudnya anak Indonesia yang berkualitas, berakhlak mulia, dan sejahtera".

Peraturan pemerintah tersebut sangat relevan dengan sumber hukum Islam yang menjadi pijakan hidup manusia dimana anak memiliki hak untuk hidup secara aman, berilmu, dan bermartabat tinggi di bawah bimbingan orang tua dan pendidik. Seorang anak perlu dibekali dengan keimanan dan ketaqwaan yang baik serta berbagai keterampilan yang memadai sejak dini, sehingga keberadaan intelektual, emosional, dan spiritual anak akan tumbuh kembang dengan kuat, diakui oleh lingkungannya, dirasakan oleh orang tuanya sebagai hamba Allah SWT yang sholeh, dan memiliki kepribadian yang menyenangkan. Muhammad Nuh, Menteri Kebudayaan dan Pendidikan RI pernah menyatakan bahwa pendidikan karakter bangsa Indonesia ini belum berhasil sesuai harapan. Hal ini dikarenakan di lembaga pendidikan, di rumah, di lembaga pemerintahan, dan di masyarakat, pendidikan karakter masih belum dilaksanakan secara optimal. Sehingga kenakalan anak, pelanggaran terhadap nilai-nilai kebenaran dan kebaikan masih marak dilakukan oleh anak-anak, remaja, maupun orang dewasa. Maka dari itu dalam mengatasi permasalahan tersebut, pemerintah tidak cukup mencanangkan peraturan karakter yang dimuat dalam perundang-undangan sajanah. $^{1}$

Al-Qur'an secara normatif memberikan spirit, inspirasi, dan motivasi dalam mendidik untuk menjadikan anak qurrota a'yun, yaitu anak yang taat pada ajarannya, berperilaku menyenangkan dan menyejukkan terhadap orang tuanya maupun lingkungannya. Maka diperlukan konsep qurrota a'yun sebagai teoriteori dari sumber yang jelas yaitu al-Qur'an dan al-Hadits, serta pemikiranpemikiran para ahli pendidikan maupun pandangan psikolog dalam membina pendidikan karakter anak yang kemudian diperjelas oleh para mufassir melalui buku-buku tafsir yang berkaitan dengan konsep qurrota a'yun tersebut serta buku-buku pendukung lainnya, sehingga dapat dijadikan pedoman bagi orang tua dan para pendidik untuk mendidik anak-anaknya. al-Qur'an secara spesifik dalam surat al-Furqan ayat 74 dan al-Sajdah ayat 17 yang diperjelas dari pendapat para mufassir dapat dijadikan sebagai konsep dalam berkarakter bagi anak karena di dalamnya dijelaskan peran dan doa dari orang tua, dan peran para pendidik dalam menyampaikan pendidikan ketaqwaan kepada anak-anaknya.

\section{B. METODE PENELITIAN}

Metode Penelitian yang digunakan adalah kualitatif, metode penyajian datanya adalah deskriptif analisis, serta dirancang dengan pendekatan kepustakaan yang menelusuri beberapa literatur yang berkaitan dengan pembahasan tentang konsep qurrota a 'yun sebagai karakter anak (studi al-qur'an surat al-furqan: 74 dan al-sajdah: 17)

${ }^{1}$ Undang-Undang Republik Indonesia No. 23 Tahun 2002, Tentang Komisi Perlindungan Anak, (Jakarta: Diknas Pusat Group. 2006), h. 10 


\section{PEMBAHASAN}

\section{Konsep Qurrota A'yun Dalam al-Qur'an}

Pengertian kata qurrota a'yun yang tertera dalam surat al-Furqan ayat 74 .

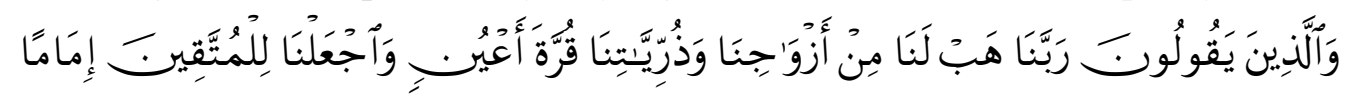

Artinya: "Dan orang orang yang berkata: "Ya Tuhan kami, anugrahkanlah kepada kami isteri-isteri kami dan keturunan kami sebagai penyenang hati (Kami), dan jadikanlah kami imam bagi orang-orang yang bertakwa."

Telah dijelaskan di dalam kitab metode praktis belajar mengajar terjemahan al-Qur'an dari kata-perkata yang disusun oleh pimpinan Islam Indonesia. Mereka menyampaikan bahwa arti "qurrota a'yun" adalah sebagai "penenang mata". ${ }^{2}$ Pengertian kata qurrota a'yun dijelaskan pula oleh beberapa ulama di antaranya:

Ibnu 'Abbas Radhiyallahu' Anhu berkata: “qurrota a'yun maksudnya adalah keturunan yang mengerjakan ketha'atan, sehingga dengan ketaatannya itu ia dapat membahagiakan orang tuanya di dunia dan di akhirat". Maka dengan keturunan yang dapat melakukan ketaatan pada Allah, ia akan menyenangkan hati orang tuanya melalui bakti maupun melalui pelayanannya. Ia selalu menyejukkan hati orang tua dan keluarga dengan membacakan dan mengajarkan mereka dalam mentadabburi al-Qur'an dan as-Sunnah. Keturunan yang taat pada Allah juga lebih bias diharapkan untuk menjaga keutuhan keluarga di atas agama yang mulia ini dan lebih bias diharapkan doanya untuk dikabulkan oleh Allah untuk kebaikan orang tua dan keluarga. ${ }^{3}$

Imam Hasan al-Bashri ketika ditanya tentang makna ayat di atas, beliau berkata: "Allah akan memperlihatkan kepada hamba-nya yang beriman, demi Allah tidak ada sesuatupun yang lebih menyejukkan pandangan mata seorang muslim daripada ketika ia melihat anak, cucu, saudara, dan orang-orang yang dicintainya taat kepada Allah Subhanahu Wa Ta'ala.

Imam Qurthubi menjelaskan makna “qurrota a'yun” bahwa sesungguhnya jika manusia diberi berkah dalam harta dan anaknya, maka matanya menunjukkan kebahagiaan karena keluarga dan kerabatnya. Sehingga ketika ia mempunyai seorang istri niscaya berkumpul di dalam dirinya angan-angan kepada istrinya berupa: kecantikan, harga diri, pandangan, dan kewaspadaan. Jika ia memiliki keturunan yang senantiasa menjaga ketaatan dan membantunya dalam menunaikan tugas-tugas agama dan keduniaan, serta tidak berpaling kepada suami yang lain, dan tidak pula kepada anak yang lain. Sehingga matanya menjadi tenang dan tidak berpaling kepada yang lainnya, maka itulah kebahagiaan mata dan ketenangan jiwa. ${ }^{4}$

${ }^{2}$ Pimpinan Islam Indonesia, 32 Ulama Islam Propinsi di Indonesia, Metode Praktis Belajar Mengajar Terjemah al-Qur'an Kata Perkata, (Jakarta, 2006 ), h. 905

${ }^{3}$ Muhammad Nasib Rifa'i, Ringkasan Tafsir Ibnu Katsir, (Jakarta: Ema Insani, 2012) h. 409

${ }^{4}$ Ibid., h. 82 


\section{Makna Qurrota A'yun Dalam Perspektif Para Mufassir}

Kata Qurrota A'yun dalam Surat al-Furqan Ayat 74 menurut Ahmad Mustafa al-Maraghi adalah orang-orang yang memohon kepada Allah agar melahirkan dari mereka keturunan yang taat dan beribadah kepadanya sematamata dan tidak menyekutukannya dengan yang lain. Orang yang beriman dengan sebenar-benar iman, apabila melihat keluarganya sama dengannya, taat kepada Allah, maka ia akan merasa senang dan gembira, ia mengharapkan mereka dapat berguna baginya di dunia selama hidup dan matinya serta bertemu dengannya di akhirat. Mereka juga memohon agar Allah menjadikan mereka para imam yang ditauladani dalam menegakkan panji-panji agama dengan menganugerahkan ilmu yang luas kepada mereka, dan memberi taufik kepada mereka untuk mengerjakan amal saleh. ${ }^{5}$

Menurut Nasib ar-Rifa'i anak yang menjadi qurrota a'yun (penyenang hati) yaitu anak yang tumbuh menjadi taat kepada Allah, tekun beribadah, menjalankan perintah Allah dan Rasulnya, menjauhkan segala apa yang dilarang dan diharamkannya. Anak qurrota a'yun dikonstruksi oleh bangunan keagamaan yang baik, sehingga hanya dapat diwujudkan dengan jalan mendekatkan anak dengan agama atau dengan memberikan pendidikan agama yang baik kepada anak. Tanpa hal itu anak qurrota a'yun selamanya akan tetap menggantung dalam alam cita, dan tidak akan pernah membumi dalam alam fakta. $^{6}$

Quraish Shihab berpendapat bahwa kata qurrota pada mulanya berarti dingin. Yang dimaksud di sini adalah menggembirakan. Sementara ulama berpendapat bahwa air mata yang mengalir dingin menunjukkan kegembiraan. Sedangkan yang hangat menunjukkan kesedihan. Karena itu pada masa lalu, dimana gadis-gadis masih malu menunjukkan perasaan atau kesedihannya menerima pinangan calon suami, para wali menemukan indicator kesedihan atau penolakannya melalui air matanya. Apabila dingin, itu berarti ia bergembira menerima pinangan, apabila hangat, itu tanda penolakan. Ada juga yang berpendapat bahwa masyarakat Mekkah pada umumnya merasa sangat terganggu dengan teriknya panas mata hari dan datangnya musim panas. Sebaliknya, mereka menyambut gembira kedatangan musim dingin, apalagi dingin di daerah sana tidak terlalu menyengat. Dari sini, kata tersebut diartikan juga dengan kegembiraan. ${ }^{7}$ Ayat ini membuktikan bahwa sifat hamba-hamba Allah yang terpuji itu tidak hanya terbatas pada upaya menghiasi diri dengan amal-amal terpuji, tetapi juga memberi perhatian kepada keluarga dan anak keturunan, bahkan masyarakat umum. Doa mereka itu tentu saja dibarengi dengan usaha mendidik anak dan keluarga agar menjadi manusia-manusia terhormat karena anak dan pasangan tidak dapat menjadi penyejuk mata tanpa keberagaman yang baik, budi pekerti yang luhur, serta pengetahuan yang memadai.

${ }^{5}$ Musafa Al-Halabi, Al-Babi Al-Halabi, Terjemah Tafsir Al Maraghi, (Semarang: Toha Putra, 1994), h. 77

${ }^{6}$ Muhammad Nasib Rifa'i, Terjemah singkat Tafsir Ibnu Katsir, Jilid IV, (Jakarta: Gema Insane, 212), h. 36

${ }^{7}$ M. Quraish Shihab, Tafsir Al-Misbah, (Jakarta: Lentera Hati, 2009), h. 164 
Sementara menurut Buya Hamka di antara sifat-sifat mereka ialah, mereka selalu bermunajat dan memohon kepada Allah agar ia menganugerahkan kepada mereka keturunan yang baik-baik sehingga istri dan anak-anaknya itu benarbenar menyenangkan hati dan menyejukkan perasaan mereka karena keluarga mereka sendiri terdiri dari orang-orang yang shaleh dan bertaqwa kepada Tuhan. Dengan demikian akan bertambah banyak di muka bumi ini hamba-hamba Allah yang Maha pengasih lagi Maha penyayang. Di samping itu mereka mereka bermunajat dan memohon kepada Allah agar mereka hendaknya menjadi penyeru manusia kepada taqwa. Ini adalah cahaya iman yang telah memenuhi hati mereka dan menerangi dengan petunjuk dan hidayah sehingga mereka ingin sekali agar orang-orang yang bertaqwa kian lama bertambah juga. Keinginan mereka agar anak cucu dan keturunan mereka menjadi pemimpin bagi orangorang yang bertaqwa bukan sekali-kali karena ingin mendapatkan kedudukan yang tinggi atau kekuasaan mutlak, tetapi mereka semata-mata karena keinginan yang tulus ikhlas agar penduduk dunia ini dipenuhi oleh orang-orang yang beriman dan bertaqwa serta agar anak cucu mereka melanjutkan perjuangan menegakkan keadilan, kebenaran, karena mereka sendiri walaupun telah meninggal dunia tetapi mereka tetap menerima pahala perjuangan anak cucunya. Sesuai dengan sabda Rasul: "Apabila anak adam meninggal maka putuslah amalnya kecuali tiga macam yaitu, sodakah yang dapat diambil manfaatnya bagi orang lain, ilmu pengetahuan yang ditinggalkannya yang dapat diambil manfaatnya sesudah wafatnya, dan anak shaleh yang selalu mendoakannya". (HR. Bukhari Muslim). ${ }^{8}$

\section{Pemahaman Mufassir Terhadap Kata Qurrota A'yun Dalam Surat al- Sajdah Ayat 17}

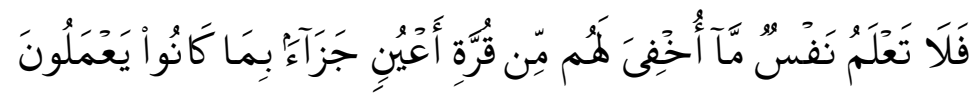

Artinya: "Tak seorangpun mengetahui berbagai nikmat yang menanti, yang indah dipandang sebagai balasan bagi mereka, atas apa yang mereka kerjakan."

Kata Qurrota A'yun Dalam Surat al-Sajdah Ayat 17 Menurut Ahmad Mustafa al-Maraghi adalah "Maka tiada seorangpun yang mengetahui pahala besar yang telah disediakan oleh Allah untuk mereka, yaitu berupa kenikmatan dan kelezatan yang abadi. Tiada seorangpun yang mengetahui pahala yang semisal dengannya, hal itu sebagai balasan yang sempurna dari ama-amal shaleh yang telah mereka kerjakan. Mereka menyembunyikan amal-amal shaleh, maka Allah pun menyediakan pahala mereka dengan sembunyi-sembunyi pula. ${ }^{9}$

Asy-Syaikhani dan lain-lainnya telah meriwayatkan sebuah hadits yang bersumber dari Abu Hurairah RA., dan Abu Hurairah RA. menerimanya dari Rasulullah SAW, yang telah mengatakan: "Allah berfirman, "Aku telah

\footnotetext{
${ }^{8}$ Hamka, Tafsir Al-Azhar, (Jakarta: Pustaka Panjimas, t.th.), h. 167

${ }^{9}$ Ahmad Al-Maraghi, Tafsir Al-Maraghi, (Semarang: Toha Putra, 1993), Cet ke 2, h. 214-
} 
menyediakan untuk hamba-hambaku yang shaleh, suatu (pahala) yang belum pernah dilihat oleh mata, belum pernah didengar oleh telinga, dan belum pernah terbetik oleh kalbu manusia'. Niscaya akan terkejutlah semuanya oleh apa yang telah aku perlihatkan kepada kalian, bacalah oleh kalian bila kalian suka. Seorang pun tidak mengetahui apa yang disembunyikan untuk mereka, yaitu (berupa bermacam-macam nikmat) yang menyedapkan pandangan mata". ${ }^{10}$

Menurut Nasib ar-Rifa'i bahwa kata Qurrota A'yun Dalam Surat al-Sajdah Ayat 17 "Seorangpun tidak mengetahui apa yang disembunyikan untuk mereka berupa perkara yang menyenangkan pandangan mata sebagai balasan apa yang telah mereka kerjakan". Tidak seorangpun yang mengetahui betapa besarnya kenikmatan abadi dan kelezatan yang tiada tara yang disembunyikan Allah untuk mereka di surge. Karena mereka menyembunyikan amalnya, maka Allah pun menyembunyikan pahala bagi mereka sebagai pembalasan yang setimpal, sebab siapa yang menanam, dia akan menuai. Hasan Bashri berkata: "Kaum itu telah menyembunyikan amalnya, karena itu Allah pun menyembunyikan bagi mereka imbalan yang belum pernah dilihat mata dan terbetik dalam benak manusia". Riwayat penafsiran ini dikemukakan oleh Ibnu Abi Hatim. al-Bukhari meriwayatkan dari Abu Hurairah RA. bahwa Rasulullah SAW bersabda: "Allah Ta'ala berfirman, 'Aku menyediakan bagi hamba-hambaku yang shaleh sesuai yang shaleh sesuatu yang tidak pernah terlihat oleh mata, terdengar oleh telinga, dan terbetik dalam kalbu manusia'. ${ }^{11}$

M. Quraish Shihab menyatakan kata Qurrota A'yun dalam Surat al-Sajdah Ayat 17 bahwa Allah sudah menyediakan kenikmatan dan kebahagiaan yang setimpal dengan usaha kebaikan yang telah dilakukan oleh hambanya yang beriman, taat beribadah, dan beramal shaleh selama hidupnya di dunia. Karena aktivitas yang dilakukan bermanfaat dan dirasakan oleh orang banyak, maka kenikmatan yang akan diterima merupakan kenikmatan yang tak pernah dirasakan saat hidupnya. ${ }^{12}$

Kata Qurrota A'yun dalam surat al-Sajdah Ayat 17 menurut Buya Hamka adalah "Seseorang tidak dapat mengetahui betapa besarnya kebahagiaan dan kesenangan yang akan diberikan Allah kepadanya di akhirat nanti, dan betapa enaknya dan nyamannya tinggal di dalam surge itu, sebagai balasan perbuatan baik yang telah dikerjakan selama hidup didunia". Diriwayatkan oleh Bukhari dan Muslim. ${ }^{13}$ Abu Hurairah RA. di dalam haditsnya, Rasulullah SAW bersabda: "Allah SWT berfirman: 'Aku telah menyediakan untuk hambahambaku yang shaleh apa yang belum pernah mata melihatnya, belum pernah telinga mendengarnya, dan belum pernah tergores di dalam hati manusia. Kecuali apa yang telah aku kemukakan kepadamu".

Perbandingan mengenai makna Makna Qurrota A'yun menurut beberapa mufassir dapat dijelaskan dalam tabel berikut.

\footnotetext{
${ }^{10}$ Ibid.

${ }^{11}$ Muham Nasib Rifa'i, Ringkasan Tafsir Ibnu Katsir, Jilid 3, (Jakarta: Gema Insani, 212), h.593

12 Ibid.

${ }^{13}$ Hamka, Tafsir Al-Azhar, (Jakarta: Panjimas, t.th), h. 167
} 
Tabel C.1. Perbandingan Makna Qurrota A'yun menurut para mufassir

\begin{tabular}{|l|l|l|}
\hline No & Tafsir & Makna Qurrota A'yun \\
\hline 1. & al-Maraghi & $\begin{array}{l}\text { Keturunan yang taat dan beribadah kepadanya semata- } \\
\text { mata dan tidak menyekutukannya dengan yang lain. }\end{array}$ \\
\hline 2. & Ibnu Katsir & $\begin{array}{l}\text { Anak yang tumbuh menjadi taat kepada Allah, tekun } \\
\text { beribadah, menjalankan perintah Allah dan Rasulnya, } \\
\text { menjauhkan segala apa yang dilarang dan } \\
\text { diharamkannya. Jadi hanya anak yang menjalankan } \\
\text { ajaran agama dengan baik dan memiliki akhlaqul } \\
\text { karimah yang dapat menjadi qurrota a'yun. }\end{array}$ \\
\hline 3. & al-Mishbah & $\begin{array}{l}\text { Anak yang menggembirakan. Sebagai sifat hamba- } \\
\text { hamba Allah yang terpuji itu tidak terbatas pada upaya } \\
\text { menghiasi diri dengan amal-amal terpuji, tetapi juga } \\
\text { memberi perhatian kepada keluarga dan anak keturunan, } \\
\text { bahkan masyarakat umum. }\end{array}$ \\
\hline 4. & al-Azhar & $\begin{array}{l}\text { Keturunan yang baik-baik sehingga istri dan anak- } \\
\text { anaknya itu benar-benar menyenangkan hati dan } \\
\text { menyejukkan perasaan mereka karena keluarga mereka } \\
\text { sendiri terdiri dari orang-orang yang shaleh dan bertaqwa } \\
\text { kepada Tuhan. }\end{array}$ \\
\hline
\end{tabular}

Dari beberapa pandangan para mufassir yang telah dikemukakan sebelumnya, mereka memaknai qurrota a'yun sebagai suatu ungkapan dan harapan kebaikan, kebahagiaan berupa sikap, perbuatan, dan ucapan anak yang selalu menyenangkan orang tua, mentaati Allah dan ajarannya, serta memiliki kualitas keilmuan yang memadai untuk mengembangkan kehidupan manusia. Pandangan mufassir tersebut menunjukkan betapa mulianya bagi orang tua dan bangsa ini apabila hadir dan bermunculan di muka bumi ini anak-anak yang memiliki kepribadian mulia, mampu membahagiakan dan menyejukkan orang tua dan bangsanya. Kepribadian menyenangkan (qurrota a'yun) akan muncul dan dirasakan oleh siapapun apabila didukung oleh kualitas keimanan, ketaqwaan, dan kualitas keilmuan yang baik dan memadai. Maka dari itu, pendidikan karakter menjadi penentu bagi kehidupan manusia terutama kehidupan dirinya sebagai hamba Allah. ${ }^{14}$

Sejalan dengan kebutuhan hidup yang aman dan menyenangkan, maka pembentukan karakter anak harus mendapat perhatian orang tua dan pendidik dengan memulai pendidikan berakidah secara benar, mentaati ajaran Allah dan Rasulnya dimulai sejak usia dini, melalui pendampingan orang tua dan pendidik serta pembiasaan-pembiasaan yang baik dalam kehidupan sehari-hari, sehingga akan melahirkan anak yang bersifat qurrota a'yun.

${ }^{14}$ Depertemen Agama Ripublik Indonesia, Syarnil Al-Qur'an The Miracle 15, (Jakarta: Sigma, 2009), h.730 


\section{Intisari Kandungan Surat al-Furqan Ayat 74 dan Surat al-Sajdah Ayat 17 a. Kandungan Surat al-Furqan ayat 74}

Surat al-Furqan merupakan surat yang ke 25 juz 19 yang artinya pembeda. Intisari kandungan yang terdapat dalam surat tersebut, yaitu anak adalah amanah. Tugas orang tua sebagai pembawa amanah tentunya membutuhkan pengetahuan yang mendalam tentang cara menjaga amanah dengan baik dan mampu memberikan bimbingan yang tepat. Beratnya beban dan tanggung jawab sebagai orang tua terkadang secara tidak disadari membuat orang tua lupa bahwa anak-anaknya adalah individu yang perlu mendapat pembimbingan dan dihargai sebagai pribadi, bukan individu yang dibatasi kesempatannya untuk mengembangkan diri ataupun dipaksa menjadi orang lain. Setiap orang tua tentunya berharap anaknya meraih keberhasilan di masa depan. Namun, orang tua sering lupa bahwa keberhasilan anak pada masa depan sejatinya adalah keberhasilan yang dating dari kebahagiaan anak.

Orang tua perlu menjaga hukum Tuhan sesudah kita, melalui istri-istri dan anak-anak keturunan kita. Di mata kita mereka bukan hanya sekedar kebetulan atau barang-barang mainan, tetapi benar-benar menyenangkan menganugerahi kerinduan rohani kita. Melalui mereka dan melalui kita sendiri dengan karunia Allah mungkin kita dapat mengajak kepada kebenaran dan ketaqwaan.

\section{b. Kandungan Surat al-Sajdah Ayat 17}

Al-Quran surat al-Sajdah merupakan surat yang ke 32 juz 21. Qurrota a'yun diungkapkan sebagai cendera mata. Sebuah ungkapan untuk segala yang sangat menyenangkan dan memberikan kepuasan sepenuhnya. Dalam keadaan sekarang, sukar sekali kita membayangkan kebahagiaan apa yang sebenarnya menunggu kita pada hari kemudian. Kebahagiaan adalah disaat orang tua memiliki anak yang menyenangkan mata dan perasaan hati karena ketaatannya kepada Allah, bermanfaat hidupnya untuk orang tuanya, maupun untuk orang lain. ${ }^{15}$

Tabel C.2. Hubungan Surat al-Furqan ayat 74 dan Surat al-Sajdah Ayat 17

\begin{tabular}{|l|l|l|}
\hline No & Surah & Penjelasan \\
\hline 1. & al-Furqan ayat & $\begin{array}{l}\text { Menjelaskan peran dan tanggung jawab orang tua } \\
\text { dan pendidik untuk membentuk berbagai } \\
\text { kecerdasan anak, terutama kecerdasan spiritual } \\
\text { anak (taqwa). Pendidikan, pendampingan, dan } \\
\text { doa yang dilakukan secara tepat oleh orang tua } \\
\text { akan menghasilkan generasi yang berkualitas. } \\
\text { Kualitas yang dimaksud dalam tolak ukur anak } \\
\text { yang qurrota a'yun adalah tingkat keimanan, } \\
\text { ketakwaan, dan ilmu pengetahuan yang baik dan } \\
\text { memadai. Hal-hal tersebut dilakukan karena } \\
\text { secara fitrahnya anak merupakan sesosok manusia }\end{array}$ \\
\hline
\end{tabular}

15 Abdullah Yusuf Ali, Terjemah dan Tafsir Juz XVI sd XXIV, (Jakarta: Pustaka Firdaus, 2009), h. 409 


\begin{tabular}{|l|l|l|}
\hline & & $\begin{array}{l}\text { yang diamanahkan oleh Allah kepada orang tua } \\
\text { untuk dikembangkan potensi ketaqwaannya dan } \\
\text { potensi-potensi lain yang dimiliki anak. }\end{array}$ \\
\hline 2. & al-Sajdah ayat 17 & $\begin{array}{l}\text { Dalam kaitannya dengan peran dan tanggung } \\
\text { jawab orang tua kepada anaknya seperti yang } \\
\text { telah digambarkan pada surat al-Fuqran ayat 74, } \\
\text { maka surat al-Sajdah ayat 17 mengomentari hal } \\
\text { ini, mengenai pengaruh pendidikan yang telah } \\
\text { dilakukan oleh orang tua dan pendidik kepada } \\
\text { anak. Hasil dari pembentukan karakter anak yang } \\
\text { baik akan melahirkan amal shaleh yang mampu } \\
\text { dilakukan oleh sang anak kepada siapapun, } \\
\text { sehingga anak dan keluarga dijanjikan akan } \\
\text { mendapat perhatian dan penghargaan berupa } \\
\text { kebaikan dan kenikmatan yang luar biasa dari } \\
\text { Allah SWT yang tidak pernah dirasakan selama } \\
\text { masa hidupnya. }\end{array}$ \\
\hline
\end{tabular}

\section{Penerapan Pendidikan Karakter Anak}

\section{a. Pendidikan Karakter Anak Oleh Pendidik}

Demi membentuk karakter anak yang qurrota a'yun, dalam penerapannya, para pendidik dapat mengaplikasikan metode Pendidikan Islam yang menyangkut karakter individual atau sosial peserta didik, hingga orang tua dan pendidik itu sendiri. Sebab metode Pendidikan merupakan sarana atau jalan menuju tujuan pendidikan, sehingga jalan yang ditempuh seorang pendidik haruslah mengacu pada dasar-dasar metode pendidikan tersebut. Dasar metode pendidikan karakter anak diantaranya adalah: dasar agamis, biologis, psikologis, dan sosiologis.

Dasar Agamis, aksudnya bahwa metode yang digunakan dalam pendidikan Islam haruslah berdasarkan pada agama. Sementara agama Islam merujuk pada al-Qur'an dan Hadits. Untuk itu, dalam pelaksanaannya berbagai metode yang digunakan oleh pendidik hendaknya disesuaikan dengan kebutuhan yang muncul secara efektif dan efisien yang dilandasi nilai-nilai al-Qur' an dan Hadits.

Dasar Biologis, bahwa perkembangan biologis manusia mempunyai pengaruh dalam perkembangan intelektualnya. Semakin dinamis perkembangan biologis seseorang, maka dengan sendirinya makin meningkat pula daya intelektualnya. Daya tangkap, penalaran, dan tingkat intelektual peserta didik yang berbeda-beda membuat para pengajar perlu untuk lebih bersabar dan tetap memperhatikan perkembangan biologis peserta didik.

Dasar Psikologis, bahwa perkembangan dan kondisi psikologis peserta didik akan memberikan pengaruh yang sangat besar kepada penerimaan nilai pendidikan dan pengetahuan yang dilaksanakan. Dalam kondisi emosional yang labil pemberian ilmu pengetahuan dan internalisasi nilai 
akan tidak berjalan sesuai dengan yang diharapkan. Oleh karena itu metode pendidikan Islam baru dapat diterapkan secara efektif bila didasarkan pada perkembangan dan kondisi psikologis peserta didiknya. Untuk itu seorang pendidik dituntut untuk peka dan berupaya mengembangkan potensi psikologis yang tumbuh pada peserta didik. Sebab dalam konsep Islam, akal termasuk dalam tatanan rohani.

Dasar Sosiologis, bahwa saat pembelajaran berlangsung ada interaksi antara peserta didik dengan peserta didik, dan ada interaksi antara pendidik dengan peserta didik. Jangan sampai ada metode yang digunakan tapi tidak sesuai dengan kondisi sosiologis peserta didik, jika hal ini terjadi bukan mustahil tujuan pendidikan akan sulit untuk dicapai.

Keempat dasar diatas merupakan satu kesatuan yang tidak dapat dipisahkan dan harus terus diperhatikan oleh para pengguna metode pendidikan Islam. Pengaplikasian keempat dasar tersebut juga harus tetap memperhatikan kecocokan kondisi agamis, biologis, psikologis, dan sosiologis peserta didik itu sendiri agar diperoleh cara didik dan penggunaan metode yang tepat. Metode yang biasanya digunakan dalam pendidikan karakter antara lain: metode ceramah, metode tanya jawab, metode diskusi, metode pemberian tugas, metode demonstrasi, metode eksperimen, metode perumpamaan (amsal), metode targhib dan tarhib, serta metode pengulangan (tirkor). ${ }^{16}$

\section{b. Peranan Orang Tua dan Pendidik Dalam Membentuk Karakter Anak}

Berikut ini adalah peranan orang tua dan pendidik dalam membentuk karakter anak yang qurrota a'yun:

1) Pendekatan Pengalaman

Pendekatan ini berarti pemberian pengalaman keagamaan kepada anak atau peserta didik dalam rangka penanaman nilai-nilai keagamaan. Dengan pendekatan ini anak atau peserta didik diberi kesempatan untuk mendapatkan pengalaman keagamaan, baik secara individu maupun kelompok.

2) Pendekatan Pembiasaan

Pembiasaan adalah suatu tingkah laku tertentu yang sifatnya otomatis tanpa direncanakan terlebih dahulu dan berlaku begitu saja yang kadang kala tanpa dipikirkan. Pendekatan pembiasaan sejak usia dini dalam pendidikan berarti memberikan kesempatan kepada anak atau peserta didik terbiasa mengamalkan ajarannya.

3) Pendekatan Emosional

Pendekatan ini adalah usaha untuk menggugah perasaan dan emosi anak di dalam meyakini ajaran Islam serta dapat merasakan mana yang baik dan mana yang buruk.

4) Pendekatan Rasional

16 Reni Akbar Hamadi, Psikologi Perkembangan Anak, Mengenal Sifat, Bakat dan Kemampuan Anak, (Jakarta: Grasindo, 2001), h. 37 
Pendekatan ini mempergunakan rasio dalam memahami dan menerima kebesaran dan kekuasaan Allah. Dengan kekuatan akalnya, anak dapat membedakan mana yang baik dan mana yang buruk, bahkan dengan akal yang dimilikinya juga anak dapat membenarkan dan membuktikan adanya Allah.

5) Pendekatan Fungsional

Pendekatan dalam rangka usaha menyampaikan materi agama dengan menekankan kepada segi kemanfaatan pada anak didik dalam kehidupan sehari-hari, sesuai dengan tingkat perkembangannya. Ilmu agama yang dipelajari anak di sekolah bukanlah hanya sekedar melatih otak, tetapi diharapkan berguna bagi kehidupan anak, baik dalam kehidupan individu maupun dalam kehidupan sosial.

6) Pendekatan Ketauladanan

Pendekatan ini memperlihatkan contoh baik (ketauladanan) secara langsung yang dilakukan oleh personal sekolah, orang tua, pendidik, dan tenaga kependidikan lainnya yang mencerminkan akhlak terpuji, maupun yang tidak langsung melalui suguhan ilustrasi berupa kisahkisah ketauladanan. ${ }^{17}$

\section{KESIMPULAN}

Konsep qurrota a'yun merupakan teori dari al-Qur'an yang tertera di dalam surat al-Furqan ayat 74 dan al-Sajdah ayat 17, sebagai sumber pendidikan Islam, serta diperkaya oleh pandangan-pandangan ahli pendidikan dan psikolog anak. Konsep ini diartikan sebagai pengetahuan dasar dalam mendidik anak sekaligus sebagai visi pendidikan Islam, yang akan memberikan solusi terhadap pendidikan anak sejak usia dini, terutama dalam mengantarkan pendidikan karakter anak, agar anak memiliki karakter baik, dapat mencintai tuhannya, dan mencintai ciptaannya, serta paham terhadap tugas dan tanggung jawabnya di muka bumi ini, yaitu sebagai abdun yang harus mengabdi kepada Allah SWT dengan penuh taqwa.

Dari beberapa pandangan oleh para mufassir yaitu: Ahmad Mustafa alMaraghi, Nasib ar-Rifa'i, M. Quraish Shihab, dan Buya Hamka tentang tafsir alFurqan ayat 74 dan al-Sajdah ayat 17, disimpulkan bahwa mereka memaknai qurrota a'yun sebagai suatu ungkapan dan harapan kebaikan, kebahagiaan berupa sikap, perbuatan, dan ucapan anak yang selalu menyenangkan orang tua, mentaati Allah dan ajarannya, serta memiliki kualitas keilmuan yang memadai untuk mengembangkan kehidupan manusia. Pandangan mufassir tersebut menunjukkan betapa mulianya bagi orang tua dan bangsa ini apabila hadir dan bermunculan di muka bumi ini anak-anak yang memiliki kepribadian mulia, mampu membahagiakan dan menyejukkan orang tua dan bangsanya. Kepribadian menyenangkan (qurrota a'yun) akan muncul dan dirasakan oleh siapapun apabila didukung oleh kualitas keimanan, ketaqwaan, dan kualitas keilmuan yang baik dan memadai. 
ISTIGHNA, Vol. 2, No 2, Juli 2019 P-ISSN 1979-2824

Homepage: http://e-journal.stit-islamic-village.ac.id/index.php/istighna

Siti Maryam

Konsep Qurrota A'yun Sebagai Karakter Anak

(Studi Al-Qur'an Surat Al-Furqan: 74 dan Al-Sajdah: 17)

Konsep dasar karakter anak dalam pandangan ahli antara lain, dasar agamis, dasar biologis, dasar psikologis dan dasar sosiologis. Pengaplikasian keempat dasar tersebut juga harus tetap memperhatikan kecocokan kondisi agamis, biologis, psikologis, dan sosiologis peserta didik itu sendiri agar diperoleh cara didik dan penggunaan metode yang tepat. Metode yang biasanya digunakan dalam pendidikan karakter antara lain: metode ceramah, metode tanya jawab, metode diskusi, metode pemberian tugas, metode demonstrasi, metode eksperimen, metode perumpamaan (amsal), metode targhib dan tarhib, serta metode pengulangan (tirkor). Peranan orang tua dan pendidik dalam membentuk karakter anak yang qurrota a'yun antara lain, pendekatan pengalaman, pembiasaan, emosional, rasional, fungsional, dan pendekatan ketauladanan

\section{REFERENSI}

Al-Imam, Fadhail Abil, Kasir Ibnu al-Hafidz, 1994, Tafsir Al-Qur'anul Azkhiim, Addamsiq: t.p.

Al-Nahlawi, Abdurrahman, 1996, Pendidikan Islam di Rumah Sekolah dan Masyarakat, Jakarta: Gema Insani Press.

Al-Maraghi, Ahmad Mustafa, 1984, Terjemah Tafsir al-Maraghi, Semarang: Thoha Putra.

Ar-Rifa'i Muhammad Nasib, 2012, Ringkasan Tafsir Ibnu Katsir, Jakarta: Gema Insani.

Abdurrahman, 2010, Cara Rasulullah Mendidik Anak, Jakarta: Azhar Risalah.

Agustian, Ginanjar Ari, 2002, Rahasia Sukses Membangun Kecerdasan Emosi, dan Spiritual (ESQ), Emotional, Spiritual Quotient, Jakarta: Arga Wijaya Persada.

Ahmad al-Anshari, Abdillah Muhammad, 1998, Tafsir al-Qurtubi, Bairut.

Ali, Abdullah Yusuf, 1994, Qur'an Terjemah dan Tafsirnya, Jakarta: Pustaka Firdaus.

Alvis, Cicago, Derajat Zakiyah, Cony R, Semiawan, 2002, Belajar Dan Pembelajaran Dalam Taraf Usia Dini, Jakarta: Prenhallindo.

Darajat, Zakiah, 1994, Pendidikan Islam Dalam Keluarga dan Sekolah, Jakarta: Ruhama.

Departemen Agama RI, 1978, al-Qur'an dan Terjemahnya, Jakarta: Depag RI.

Departemen Agama RI, 2009, al-Qur'an Bayan, Jakarta: Bayan Qur'an.

Departemen Agama RI, 2007, al-Qur'an Terjemah Perkata, Jakarta: Sigma.

Departemen Agama RI, 2009, al-Qur'an Syahril, Jakarta: t.p.

Dwiyono, Iriyanto, 2006, Membangun Keluarga Cerdas Dunia Akhirat, Jakarta: Aksara Indonesia.

Hamka, 1996, Tafsir al-Azhar, Jakarta: Panjimas.

Hawadi, Akbar Reni, 2007, Psikologi Perkembangan Anak Mengenal Sifat-Sifat, Bakat Anak, Jakarta: Panjimas. 
ISTIGHNA, Vol. 2, No 2, Juli 2019 P-ISSN 1979-2824

Homepage: http://e-journal.stit-islamic-village.ac.id/index.php/istighna

Siti Maryam

Konsep Qurrota A'yun Sebagai Karakter Anak

(Studi Al-Qur'an Surat Al-Furqan: 74 dan Al-Sajdah: 17)

IAIN, STAIN, PTAIS, Fakultas Tarbiyah, 1999, Ilmu Pendidikan Islam, Bandung: t.p.

Jamaris, Martini, 2003, Perkembangan Dan Pengembangan Anak Usia Taman Kanak-Kanak, Jakarta: t.p.

Malik, Fajar, 2010, Mendidik Anak Ala Muhammad, Yogyakarta: Sketsa.

Megawangi, Ratna, 2005, Terbaik Untuk Buah Hati, Jakarta: MQS Publishing.

Nata, Abudin, 2014, Perspektif Islam Tentang Strategi Pembelajaran, Jakarta: Kencana Pranada Media Group.

Novan, Ardy Wijaya, 2013, Bina Karakter Anak Usia Dini, Jakarta: Ar-Ruz Media.

Qayyim, Ibnul, 1998, Pesan-Pesan Spiritual, Jakarta: Gema Insani Press.

R. Coni, 2001, Penerapan Pembelajaran Pada Anak, Jakarta: Indeks.

Sayyid Qutub, 2000, Tafsir Fi Zilalil Qur'an (Di bawah Naungan al-Qur'an) Terjemahan Asad Yasir dkk, Jakarta: Gema Insani Press.

Shabir, Muslich, 1989, Terjemah Riyadlus Shalihin, Semarang: Putra.

Shihab, M. Quraish, 2012, Tafsir al-Misbah, Jakarta: Lentera Hati.

Syarif, Adnan, 2002, Psikologi Qur'ani, Jakarta: Pustaka Hidayah.

Sulhan, Najib, 2010, Pembangunan Karakter Pada Anak, Surabaya: Intelektual Club.

Supriyono Widodo, Ahmadi Abu, 2004, Psikologi Belajar, Jakarta: Rineka Cipta.

Syalwan, Muhammad Ali, 2003, Wahai Ayah dan Ibu Didiklah Anakmu, Yogyakarta: Daar Al-Qasim.

Tafsir, Ahmad, 1995, Pendidikan Agama Dalam Keluarga, Jakarta: t.p.

Thalib, Muhammad, 1996, 50 Pedoman Mendidik Anak Menjadi Shaleh, Bandung: Irsyad Baitu Salam.

Ulwan, Abdullah Nashih, 2007, Pendidikan Anak Dalam Islam, Jakarta: Pustaka Amani.

Undang-undang di Indonesia, No. 23, th, 2002. Tentang Perlindungan Anak, Jakarta: t.p.

Yahya, Jaya, 2004, Bimbingan Konseling Agama Islam, Jakarta: Angkasa Raya.

Zainuddin, St, 1994, Anak Dan Lingkungan Menurut Pandangan Islam, Jakarta: Andes Utama Prima. 